\title{
PKM-MEKANISASI PRODUKSI PETIS UDANG DI UD.MURNI SIDOARJO
}

\author{
Samsul Huda' ${ }^{1)}$, Siti Naviah ${ }^{2)}$, Natasya habibah ${ }^{3)}$ \\ 1,2Fakultas Pertanian Universitas Dr. Soetomo Surabaya \\ ${ }^{3}$ Fakultas Teknologi Pertahanan Universitas Pertahanan \\ Email:Isamsulhuda@unitomo.ac.id, ${ }^{2}$ titieknaviah@gmail.com \\ 3tasyabibah@,gmail.com
}

\begin{abstract}
Abstrak
Petis merupakan produk olahan, sebagai campuran untuk menambah citarasa khusus. Tujuan untuk memberikan solusi pada produsen utamanya dalam peningkatan kuantitas dan kualitas produk. Lokasi ditentukan secara purposive di Kabupaten Sidoarjo. Hasil pengabdian ini menyimpulkan bahwa: penggunaan pengaduk manual memiliki nilai tambah sebesar Rp.17.270,-dan prosentase keuntungan $69.11 \%$, sedangkan yang menggunakan mekanisasi mesin nilai tambah Rp.25.850 dengan prosentase keuntungan $87.10 \%$, secara organoleptik tektur produk petis lebih halus, mengkilat dan fleksibel.
\end{abstract}

Kata kunci: Petis, mesin pengaduk, tekstur produk.

\begin{abstract}
Petis is a processed product, as mixture to add a special flavor. The aim is to provide solutions to its main producers in increasing the quantity and quality of products. The location was determined purposively in Sidoarjo Regency. The results of this dedication conclude that : the use of a manual stirrer has added value of Rp.17,270 and profit percentage of $69.11 \%$, while those using machine mechanics added value of Rp.25,850 with a profit percentage of $87.10 \%$, organoleptically the texture of petis products is smoother, shinier and more flexible.
\end{abstract}

Keywords: Petis, mixer, product texture.

\section{PENDAhULUAN}

Usaha produksi petis udang ini sebagai mitra berada di Kecamatan Sekardangan Sidoarjo. Bentuk usahanya turun temurun dengan memperkerjakan 5 orang tenaga kerja tetap, dampak keberadaan usaha ini sangat membantu warga sekitar utamanya dalam penyediaan lapangan kerja serta meningkatkan pengembangan perekonomian setempat. Kegiatan operasional produksinnya tergolong sederhana, belum menggunakan mesin modern dalam proses produksinya, salah satu kendalanya adalah proses pengadukan filtrat sari udang masih dilakukan secara manual, sebagai bahan utama terciptanya kualitas mutu produk terbaik. Program kemitraan ini dilaksanakan dengan menerapkan mekanisasi pada proses pengadukan filtrat sari udang sebagai faktor utama dalam proses produksi secara efisien dan efektif dengan tujuan untuk menghasilkan petis udang yang memenuhi standar keamanan pangan bagi konsumen.

Berdasarkan hasil identifikasi dan analisis situasi didapatkan beberapa permasalahan yang perlu segera dicari solusi alternatifnya yaitu : Kecepatan dan efisiensi pada proses perebusan dan pengolahan bahan baku dalam upaya meningkatkan kuantitas produk sesuai target produksi serta peningkatan mutu hasil produk terutama 
tektur produk yang dihasilkan sesuai standar kualitas dan keamanan pangan bagai konsumen akhir. Karena itulah perbaikan manajemen teknis dilakukan dalam upaya peningkatan daya saing produk dan memperluas jangkauan penguasaan pasar tingkat regional. Adapun solusi yang dilaksanakan sebagai berikut :

a.Aspek efisiensi proses perebusan bahan baku yang lebih efisien terutama dari segi penggunaan waktu, dan biaya. Hal ini dilakukan dengan mekanisasi proses pengadukan menggantikan tenaga manual, hal ini berpengaruh terhadap peningkatan capaian target kuantitas bahan produk yang diolah, sehingga berdampak pada peningkatan produksi.

b.Aspek kualitas produk yang di hasilkan difokuskan pada pengembangan disain mesin pengaduk agar proses pengadukan stabil, efektif dan efisien pada proses terbentuknya filtrat sari udang sebagai faktor utama dalam menciptakan produk petis yang sempurna sehingga secara organoleptik produknya lebih halus, mengkilat dan fleksibel. Metode pelaksanaan pengabdian ini dilakukan dengan cara diskusi dan penyamaan persepsi dengan tujuan untuk mengakomodir keinginan berbagai pihak sehingga implementasi di lapangan dapat berjalan sesuai rencana dan berkelanjutan, tahapan berikutnya adalah pelatihan dan pendampingan bidang teknis meliputi pengenalan disain mesin pengaduk bahan baku dan penggunaan mesin pengaduk dalam proses produksi filtrat sari udang. Pelaksanaan pengabdian ini meliputi kegiatan diskusi dan persamaan persepsi guna mengakomodir keinginan berbagai pihak sehingga implementasi di lapangan dapat berjalan sesuai rencana dan berkelanjutan, tahapan selanjutnya adalah pelatihan dan pendampingan bidang teknis tentang pengenalan disain mesin pengaduk bahan baku serta peragaan penggunaan mesin pengaduk dalam proses produksi filtrat sari udang.

\section{HASIL DAN PEMBAHASAN}

Sekardangan Sidoarjo merupakan salah satu kabupaten di Jawa Timur dengan posisi jarak dari kampus ke lokasi Mitra $18.28 \mathrm{~km}$, waktu tempuh 1,5 jam. Pada lokasi ini terdapat 1 (satu) mitra bergerak pada produk "Petis udang". Keberadaanya mempunyai kontribusi pada perekonomian setempat serta berperan penting dalam hal penciptaan tenaga kerja utamanya warga sekitar. Tujuan program ini adalah memberikan solusi alternatif terhadap beberapa permasalahan yang dihadapi oleh produsen agar dapat berkembang berkesinambungan. Secara rinci diagram alur proses pembuatan petis tersebut pada Gambar1. berikut :

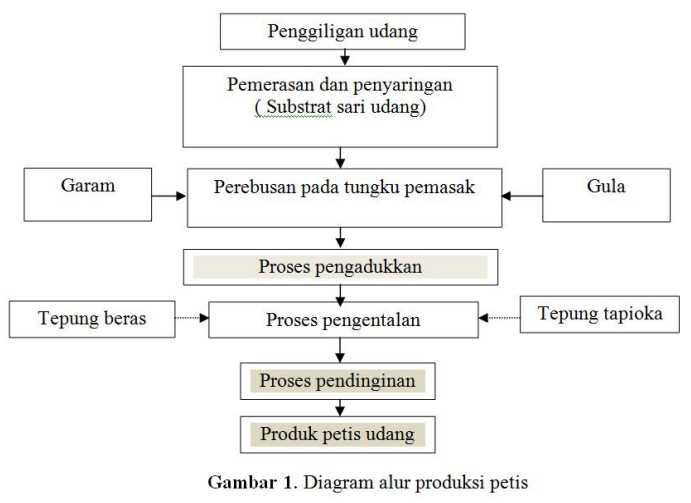

\section{a.Proses pengolahan}

Tahapan dalam pengolahan bahan baku adalah proses pengadukan yang diawali dahulu dengan pembuatan filtrat sari udang dan proses perebusan pada tungku pemasak, proses ini masih menggunakan tenaga manual dengan alokasi waktu penyelesaian 3 (tiga) jam dalam sekali proses, pada penggunaan mesin pengaduk hanya dibutuhkan waktu 1 jam untuk sekali proses, pada kenyataanya proses ini menghasilkan tambahan penghasilan berupa limbah atau ampas udang untuk digunakan sebagai tambahan makanan ternak, bahkan berdasarkan penelitian mengandung bahan berharga seperti kitin, protein, enzim, mineral, pigmen alami melalui deproteinasi enzimatik dan autolisis (Sjaifullah, 2015). Berdasarkan hasil uji proksimat yang dilakukan oleh (Dompeipen, 2016) kadar protein dan lemak mengalami penurunan setelah proses demineralisasi, deproteinisasi dan deastilasi (14,79\% menjadi $0,5 \%$ dan $2,47 \%$ menjadi 
$0,29 \%$ ) namun berbanding terbalik dimana karbohidrat naik

dari $0,74 \%$ menjadi $12,33 \%$, senyawa secara fisika dan kimia menghasilkan kitin dan kitosan. Kelanjutan proses inilah yang menentukan kuantitas dan kualitas produk, kenyataannya proses pengadukkan masih dilakukan secara manual, sehingga pada pendampingan dan penyuluhan ini dikenalkan dan dijelaskan model mekanisai penggunaan mesin pengaduk guna meningkatkan kecepatan dan kuantitas pengolahan bahan baku sesuai target serta efisiensi dalam penggunaan tenaga kerja. Proses pengadukan ini termasuk dalam tahapan pengolahan dengan hasil tektur agak kental (Intermediate Moistured) dan elastis dengan warna coklat hingga kehitaman tergantung pada proses dan bahan yang digunakan, dimana guna menghasilkan mutu petis super berasal dari perasan pertama agar dapat menghasilkan konsistensi yang pekat. Pada proses pengolahan secara kimia produk ini berasal dari cairan tubuh udang yang terbentuk pada waktu proses penggaraman kemudian diuapkan melalui proses perebusan menggunakan mesin pengaduk sehingga menjadi lebih padat seperti pasta. Ciri petis baik adalah berwarna coklat kehitaman, cerah dan berbau sedap dengan tekstur halus. Sedangkan proses fermentasi yang tepat dapat meningkatkan antioksidan dan nilai gizi, di

pasaran komposisi gizi ini bervariasi tergantung pada bahan dan cara yang digunakan, pemanfaatan limbah produknya dimanfaatkan untuk meningkatkan nutrisi campuran pakan ikan (Wong, 2016), selain itu produknya sebagai sumber nutrisi dan antioksidan alami yang baik (Prapasuwannakul, 2015) kaya akan lemak dan protein dan sebagai suplemen bernilai tinggi (Bueno Solano, 2009).

\section{b. Efektifitas pengolahan bahan baku}

Keberhasilan peningkatan kuantitas dan kualitas produksi petis udang tergantung pada kecepatan dan ketepatan dalam menciptakan filtrat sari udang yang segera dalam proses selanjutnya yaitu perebusan dalam tungku, pada proses penyaringan bahan baku (Chung, 2019) menggunakan iradiasi 1-7 kGy dengan sinar gama, bahkan untuk menjaga kesegaran bahan baku udang digunakan pardaxin dan natrium erythorbate (Hsu, 2010). Keterkaitan proses teknis dan kimia ini menghasilkan sinergi dalam pencapaian kuantitas dan kualitas produk, dimana proses penggunaan mesin pengaduk selain dapat mengefisiensikan waktu kerja, biaya dan meningkatkan produksi juga meningkatkan mutu.

\section{c. Aspek keuntungan mekanisasi}

Pada proses produksi ini membandingkan antara proses pengadukan secara manual dengan menggunakan mekanisasi, baik secara kuantitas maupun kualitas produk guna mendapatkan produk efsien dann efektif untuk memaksimalkan prosentase keuntungan dan nilai tambah. Berdasarkan hasil pencatatan selama proses produksi analisis nilai tambah sebesar Rp.17.270,- dan prosentase keuntungan 69.11 $\%$ (produksi dengan mesin pengaduk secara manual), sedangkan yang menggunakan mekanisasi mesin pengaduk sebesar Rp.25.850 dengan prosentase keuntungan $87.10 \%$, hal ini dipengaruhi oleh efisiensi penggunaan faktor produksi utamanya pada waktu proses pengadukan dan jumlah bahan baku yang digunakan dalam membuat filtrat sari udang penentu mutu dari petis udang yang dihasilkan. Secara rinci perhitungan perbedaan nilai tambah produksi dan prosentase keuntungan petis udang terdapat pada Tabel 1. berikut :

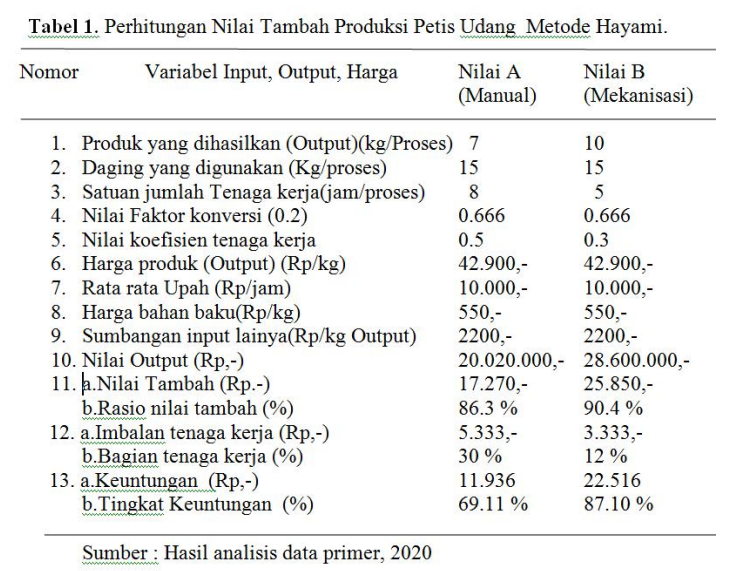




\section{KESIMPULAN}

Berdasarkan hasil pendampingan dan penyuluahn selama proses pembuatan petis udang dapat disimpulkan sebagai berikut :

Pada tahapan proses perebusan bahan baku yang menggunakan mekanisasi mesin penggunaan waktu dan biayanya lebih efisien dibandingkan dengan proses secara manual, hal ini berdampak terhadap peningkatan capaian target kuantitas bahan produk yang diolah, sehingga terjadi peningkatan produksi. Pada aspek kuantitas dan kualitas produk hasil mekanisasi prosesnya pengadukan lebih stabil, efektif dan efisien sehingga secara organoleptik tektur produk petis lebih halus, mengkilat dan fleksibel. Perlu adanya uji organoleptik lanjutan terhadap hasil produk terutama variabel rasa, warna, bau dan tekstur serta perlunya proses pengemasan selama proses pemasaran sesuai standar keamanan produk pangan.

\section{UCAPAN TERIMA KASIH}

"Artikel ini ditulis oleh (Samsul Huda Fakultas Pertanian/Perikanan) berdasarkan hasil pengabdian PKM-Mekaninasi Produksi Petis Udang di UD. Murni Sidoarjo yang dibiayai oleh Universitas Dr. Soetomo Surabaya melalui Program DIPA Nomor : AA.238/B.2.05/II/2020 tanggal 20 Februari 2020

\section{REFERENSI}

Bueno-solano, C., López-cervantes, J., Campas-baypoli, O. N., \& Lauteriogarcía, R. (2009). Chemical and biological characteristics of protein hydrolysates from fermented shrimp by-products, 112, 671-675. http://doi.org/10.1016/j.foodchem.2008. 06.029

Chung, N., Ameer, K., Jo, Y., \& Kwon, J. (n.d.). Comparison of electronic sensing techniques for screening dried shrimps irradiated using three types of approved radiation with standard analytical methods. Food Chemistry, 286(2019), 395-404.

http://doi.org/10.1016/j.foodchem.2019. $\underline{02.038}$

Dompeipen, E. J., Kaimudin, M., Dewa, R. P., Riset, B., Ambon, I., Cengkeh, J. K.,
\& Ambon, B. M. (n.d.). Isolasi kitin dan kitosan dari limbah kulit udang, 092.

Hayami Y, Kawagoe T, Morooka Y, Siregar M. 1987. Agricultural Marketing and Processing in Upland Java A Perspective From A Sunda Village. Bogor : CPGRT Centre.

Hsu, W., Lai, Y., \& Wu, S. (2010). Effects of the anti-microbial peptide pardaxin plus sodium erythorbate dissolved in different gels on the quality of Paci fi c white shrimp under refrigerated storage. Food Control, (2016), 1-8. http://doi.org/10.1016/j.foodcont.2016.0 9.025

Prapasuwannakul, N., \& Suwannahong, K. (1877). Chemical composition and antioxidant activity of Klongkone shrimp paste. Procedia - Social and Behavioral Sciences, 197, 1095-1100. http://doi.org/10.1016/j.sbspro.2015.07. $\underline{351}$

Sjaifullah, A., \& Santoso, A. B. (1876). Autolytic Isolation of Chitin from White Shrimp ( Penaues vannamei ) Waste, 18(Mcls 2015), 49-52. http://doi.org/10.1016/j.proche.2016.01. 009

Wong, M., Mo, W., Choi, W., Cheng, Z., \& Man, Y. (n.d.). Recycle food wastes into high quality fi sh feeds for safe and quality fi sh production. Environmental Pollution, (2016). http://doi.org/10.1016/j.envpol.2016.06. 035 